\title{
Biography Meets History: Communist Party Lives in International Perspective Introduction
}

$\mathrm{T}$

HE POST-COLD WAR ERA has witnessed a proliferation of biographical studies of Communist Party militants by researchers eager to unpack the often complex lives of both leading Party figures and ordinary Party members. In some respects, the post-Soviet environment has extended the frontiers of the existing clash between the "new" and "traditional" schools of Communist Party historiography, yet in other senses it has redefined the terrain on which that conflict remains joined.

The collapse of the Soviet Union, and the demise or reinvention of so many Western Communist parties, have unlocked previously inaccessible archival material not only in Moscow but in the basements of national Communist Party headquarters across the world - with, of course, notable exceptions, such as the records of the Communist Party of France (PCF), and the access limitations still evident in Moscow. The work of some Communist historians published since "the opening of the books" has claimed that the information revealed in these official files is now sufficient to support a wholly accurate institutional history of domestic Communist parties in which their "true nature" is uncontrovertibly proven (Haynes, 1996; KHF, 1995; KH, 1998). Leaving aside a number of questionable assumptions underlying this approach (not least that the files can be relied on to reveal unproblematic "facts," which in turn can be pieced together to reveal the "whole" story), some of these institutional histories have tended to generate essentially mechanical and monolithic images of Communist organizations, in which endless disputes regarding the relationship of the center to the periphery, the imperatives 
of "the line" and the disciplines of democratic centralism define the contours of the Party and dictate the political horizons of its members. It is far from axiomatic that institutional Party histories are compelled to embrace such restraints and indeed many have taken a much more complex and nuanced approach, but in some instances there appears to be a close correlation between methodological proclivity and authorial intent. In many respects the expansion of archival sources has made biographical studies of Communist Party members even more relevant than before as a useful corrective to "excess institutionalism" - enabling the historical account to incorporate agents and actors, to unpack "the mass," to locate the individual, to reinstitute subjectivity and contingency, and to assess both the common and the distinctive in comparative Communist experience (Morgan, 2001).

In recent years, the opening up of the archives and the availability of significant autobiographical material from within Communist parties' archives has led, particularly in France and latterly in the United Kingdom, to the adoption of a prosopographical methodology in the study of Communist parties (see Pennetier Pudal, 2002; MCF, 2005b). Prosopography - the study of organizations or groups through the collective analysis of the backgrounds, beliefs, relationships and activities of the individuals that make up the membership of that organization or group - offers a methodology that brings together biography and institutional history. By telling the story of the Party through the collective experiences of its members, this method places human agency and complexity at the center of the history, while the details of life stories firmly root communism in the regional and national contexts in which the parties operated.

Prosopographical and biographical approaches are manifestly applicable to the study of many, if not all, types of political and nonpolitical organizations and the individuals that join them. Indeed, attempts are being made to extend these methods to histories of social democratic parties, including the British Labour Party, as well as other left-wing organizations. Nevertheless, there are advantages to applying prosopographical methods to Communist parties, for it is true that, on a scale probably unique for any political movement, the Comintern and individual Communist parties actively encouraged the production and retention of autobiographical accounts of their members' backgrounds and political lives. The availability of significant numbers of these autobiographies has meant that a prosopog- 
raphy or collective biography of Party activists and members is now a realistic and achievable objective. While some Communist historians continue to declare the historical controversies of Communism settled by the opening of the archives, the growth of biographical studies is, in part, an acknowledgement that the interpretive environment is not yet defined by such simple "certainties."

Biography's position within the historiography of political parties of whatever hue has never been fully secure. Alongside "oral history" and other forms of personal testimony, biography and autobiography have long been dismissed by many practitioners of history - for being unreliable, lacking "objectivity," and for attempting to equate partial, individual narrative perspectives with properly balanced, and soberly weighted, historical accounts. Initially, biography secured a tentative purchase within the lexicon of labor and left historiography as part of the challenge to history as "the story of great men" (Carr, 45, 47-49). Yet while it was recognized by some that good biography could make its contribution to historical research, it remained seen as a separate discipline and not "history itself," which was concerned with the whole rather than the individual. However, as the critiques proposed by "social historians" became more forceful, biography, autobiography and other forms of personal testimony came to be accepted more widely as a legitimate form of historical record. Some advocates of the use of personal testimony have argued that with its myths, absences and partiality it should form the basis of a different type of history (Portelli, 1998), while others have seen it, more straightforwardly, as potentially important source material requiring the same level of checks and balances as other evidential data (Hobsbawm, 1998, 247-8). In the fields of social history, labor history, feminist history, black history and others, biography has long been championed as an important means through which the lives of those "hidden from history" or enduring the "condescension of posterity" might be recovered (Rowbotham, 1977; Thompson, 1981, 12).

However, before the close of the Cold War, Communist biography, even in the West, yielded little of the hoped-for potential of the form. With almost insurmountable constraints placed on independent researchers, much biographical work tended to remain the province of Party members themselves. Officially sanctioned biographies, penned by authorized Party scribes, usually displayed the 
most pronounced tendencies towards personal and institutional selfjustification. Most were rarely able to step outside the territory of hagiography, producing accounts which used and distorted lives for openly acknowledged didactic purposes, erasing all doubt, unorthodoxy and dissidence along the way (for an exemplar of this genre, see Mahon, 1976). Mirroring the distortions of these accounts, disenchanted ex-members, encouraged by opponents of the Communist movement, produced both hostile biographies of former comrades and redemptive autobiography, in which once again potentially insightful personal life stories were usually overwhelmed by other more pressing concerns such as recantation and the determination to vilify former comrades (for British examples of the form, see Hyde, 1950; Darke, 1952).

Since the disintegration of the Soviet bloc, contemporary historians of Communist parties, in Britain and elsewhere, including Callaghan, Agosti, Morgan and Ryan, have employed biography as a tool to shed light on the political sociology of Communist organizations and the lives of their members (Callaghan, 1993; Morgan, 1994; Agosti, 1996; Ryan, 2000). This new trend has encompassed not simply individual biography, but also prosopography or collective biography, and has stimulated the continued growth of "autobiography from below" - with, in the British case at least, increasing numbers of individual former Party members and activists producing their own life testimonies, many, of necessity, self-published or deposited directly into the archives.

At its most effective, critical Communist biography enables us to question myths, both of "the Party" and of its critics. It allows the historian to reconceive the Party more as a collection of individuals and cross-currents, and less as an undifferentiated whole undistinguished by levels of commitment, discipline or senses of loyalty and belonging. In particular, it allows the historian to achieve a better view of Party members, in terms not only of their formal ideological commitment to Communism and to the Party organization, but also of other affiliations, attachments and influences - notably those of nationality, ethnicity, religion, class, gender, occupation, age, family and other social relations. Biographical study helps to locate the individual within not only the Party but also within the wider matrix of social, political and cultural relations and frameworks. This, in turn, makes it easier for the historian to reconstruct the ties that fix the 
Party in the wider labor movement, in national and international contexts. As such, the adoption of a biographical approach encourages historians to advance the notion of complexity in the construction of Communist identities and to recognize the importance of differentiation in the writing of Party histories, and urges historians to move beyond the implicit assertion of an unproblematic match between institutional and individual life histories.

And yet, as the historiographical debate moves forward, there are encouraging signs of an erosion of bipolar approaches to the recounting of Communist Party history. With the legitimacy of biographical treatments now more widely accepted, and a continuing recognition of the value and importance of sophisticated organizational Party histories, there are hopeful indications that the breach between the social and institutional historical schools might be mended. It is possible that a new labor history, one that is not collapsed into a social history of the working class, but is able to populate the institutions of that class (and which places at its center the relationship between the human actor and the institution), might be an end result of such a reconciliation. If that process remains tentative, it is still clear that, in a post-Soviet context, there is little to be gained by asserting the preeminence of any singular historiographical method over another.

The six biographical studies presented here have their origins in a conference organized by the Communist Party of Great Britain Biographical Project (CPGB-BP), involving researchers from the Universities of Manchester and Liverpool. This project sought, via the development of a searchable database of British Communist Party members, to combine both qualitative and quantitative data, enabling for the first time a prosopographical study of British Communism. The project was, in part, a recognition a decade after the opening of the official Party archive, of the limitations of CPGB historians' existing knowledge of the political sociology of British Communism and the life experiences of CPGB members. In attempting to construct a deeper and more complex collective biography, the Project sought to examine the family backgrounds, motivations and attitudes of CPGB members; their industrial, cultural and educational activities; and their involvement in all aspects of local and international campaigning. With material drawn from a wide range of archival and primary sources, and supplemented by more than 100 new interviews with CPGB members (recordings of which have since been depos- 
ited with the National Sound Archive in London), the CPGB-BP database has the potential to become an important - and, for historians of the composition, motivations and activities of British Communism, an unparalleled - research resource, the worth of which is already being demonstrated in published work. (For a fuller discussion of the work of the Project see MCF, 2005b.)

The Project conference, held at the University of Manchester, England, April 7-9, 2001, was entitled "People of a Special Mould?"1 In resetting Stalin's assertion of the essential "distinctiveness" of Communists as a question, the conference's organizers encouraged participants to explore the ways in which Communists - positively or otherwise - might be considered "atypical" political actors: within their own national working-class and labor movements; by way of their own political practice distinct from others on the left; or in relation to Communism's ideological ambitions or international political hierarchies. Inevitably, and quite reasonably, what emerged at the conference was not a singular, discrete "answer" to the question, but an array of often fascinating reflections on the conundrum of Communist identity and practice, attuned, in particular, to the balance between specificity and comparative convergence in the domestic and international spheres of Communist Party history.

Some participants presented prosopographical accounts, while others concentrated on individual biographies. In both cases, however, a recurrent theme was the importance of acknowledging the often plural and conflictual nature of the identities that Communist activists struggled to sustain. Their efforts to merge what could appear to be irreconcilable political imperatives were not always successful, and the personal costs of their efforts could be calamitous. These difficulties are in themselves an important reason why such biographical accounts remain a vital component of an accurately populated history of international Communism. ${ }^{2}$

1 The Communist Party of Great Britain Biographical Project and the "People of a Special Mould" conference were both funded by ESRC award number R000 237924.

2 A selection of the Comintern biographies from the conference has been published in Agents of the Revolution (MCF, 2005a). Issues involving the Comintern did not exhaust the controversies aired at the conference, nor did all papers focus exclusively on moments of "high drama" or of Party "crisis." Other papers dealing with cultural and countercultural activities by Communists from all corners of Europe, ranging in focus from the 1920 s to the close of the 1980 s, were published in 2002 in the "Red Lives" edition of the journal Socialist History (SH, 2002). 
All four of the articles presented here analyze the lives of Communist Party activists whose commitment and contribution to the prosecution of "the cause" is not in doubt - even if the political contexts in which they labored, and the individual strategic and tactical approaches these encouraged, differed markedly. Although the significance of each of the political actors documented here itself warrants the attention afforded them, the cumulative picture of Communist activism that emerges in these accounts admirably demonstrates the ability of biography to both highlight the general and isolate the particular in political lives united by an apparently "universalist" ideology.

Hakim Adi's study of the Ghanaian-born British Communist activist Desmond Buckle, one of the first African members of the Party, not only recreates the life history of a neglected figure in the CPGB whose responsibility for international political affairs on the Party's behalf was substantial, but indicates stubborn imbalances in the existing historiography of the British Party, which continue to impede a full appreciation of the role of key figures within the CPGB's black cadre.

Pirkko Kotila's account of Hertta Kuusinen, without question the most renowned Communist woman in Finland in the post-Second World War period, reveals an effective parliamentarian, a skilled journalist and broadcaster, and a practical advocate of coalitions among the sectors of a divided domestic left. Kotila's study sheds light on a figure largely obscured by the international political reputation of her Communist father; makes clear the multiple repercussions for Finland's "revolutionaries" of the country's geopolitical proximity to the USSR; and, at the same time, indicates the dramatic effects her unwavering commitment to the international Communist movement had on her family and other personal relations in her life.

Gary Murrell's assessment of the life of American academic and CPUSA theoretician Herbert Aptheker documents the life of a figure certain to be more familiar to many readers of Science $\mathcal{E} 2$ Society. Yet here he reveals, with the active cooperation of Aptheker himself (with whom Murrell was in close contact until just weeks before his death), the continuities and ruptures in a political career spanning seven decades. In doing so, Murrell identifies the opportunities and obstacles that academics, even of Aptheker's status, faced as they sought to influence Party policy. At the same time, Murrell demonstrates 
the powerful conditioning influence that Aptheker's sense of loyalty to the Party, on the one hand, and its ideology, on the other, exerted over his own work and sense of political identity - a distinction finally pushed past the point of no return at the Party's convention in 1991.

The comparative assessment of three pre-eminent Communist miners' leaders - Arthur Horner (Britain), Willie Agatz (Germany) and Edward Gierek (Poland) - provided by Nina Fishman, Anita J. Prazmowska and Holger Heith, confirms the complex calculations that faced both Communist Party officials and Communist miners' leaders (on both sides of the European divide) during the coal-fired decades of postwar reconstruction. What emerges is a picture of proud and independent-minded industrial militants, convinced of the justice of the miners' cause (and their personal appraisal of it), yet anxious not to jeopardize the greater social benefits that wholesale economic revival seemed to promise. One of the ways in which these leading industrial Communists differed is in how, over time, they tried to reconcile the competing pressures bearing down on them from their respective governments, their own over-zealous union members, and their "more ideological" Party comrades. Ultimately, their individual sense of the opportunities (and disappointments) that confronted them, once the economic and political contours of postwar Europe became clearer, led them in significantly different personal and professional directions.

The diversity of "Party lives" documented here does not lend itself to simple thematic generalizations about the nature of Communist activism or commitment. Indeed, the absence of such uniformity is telling in itself. That the political and personal lives of such Communists as these were not so "predictably" orthodox, nor so narrowly instrumental, is not in itself a revelation. Yet this simple observation continues to discomfort those institutional - and, often, anti-Communist - historians whose interest in the "personal component" of Communist history rarely extends beyond leadership functionaries, where it exists at all. The recognition of the importance of personal, human agency remains one of the simplest, and most compelling, justifications that biographical historians can deploy for their approach.

It should, however, be self-evident that biography ought not to be used to replace the narrow certainties of institutionalism with a 
new (and equally disabling) orthodoxy — one in which the individual lives of Communist militants are seen as infinitely particular. The shared experience of political affiliation and of Party membership underscored the lives of all active Communists, and some of the most fundamental components of Communist identity remained the "common property of all."

All of them wrestled with the dilemmas of fusing principled political aspirations with pragmatic daily practice. Each of them struggled to reconcile their determination to act effectively with upholding the discipline required by the Party, especially when these aims appeared in conflict. All of the Communist activists analyzed in these essays operated in a context defined not only by social democracy but also by the shadow (or, as some of them believed, the light) cast by Moscow and the CPSU. For some of them, the "Soviet dimension" would at times prove geopolitically and ideologically decisive, but for others the Kremlin appeared to be a more distant political master. Operating in the postwar world, each one sought to come to terms with wider society and to construct roads to socialism specific to their national or international contexts. Most of the figures presented here were, to varying degrees, drawn towards Communist and left politics through the influence of family relationships and the social environment in which they grew up - despite their notably different family backgrounds. For several of them, their identities as Communists seem to have been closely related to their parallel identity as an "outsider" - either as an immigrant or a member of a minority group, or as someone threatened by social, professional or economic exclusion. However, the caveats that apply to even these bald generalizations demonstrate the challenge of producing accurate and illuminating comparative life histories, let alone full prosopographical analyses of Communist Parties.

Methodologically speaking, one of the imperatives of Communist biography confirmed by this collection is the need to recognize the full range of political identities to which such "Party" militants felt an attachment. Here are Communists who appeared to prize equally their status as a pragmatic and astute trade unionist; as a "progressive" parliamentarian; as a "radical" academic, or as a committed anti-colonial advocate and campaigner against racial injustice. Yet, as these life histories suggest, such a plural sense of political affiliation could generate difficulties for its advocates, alongside greater 
political opportunities - particularly when it clashed with the assumptions of discipline and loyalty demanded of "good" Party members. Biographical studies of the caliber of those on offer here enable us to explore the many intersections, parallel pathways and blocked crossing-over points in the lives that these "special people" traveled.

RichaRd CROSS

ANDREW FLINN

Boots Library

Nottingham Trent University

Goldsmith Street

Nottingham NG1 5LS

United Kindgom

richard.cross@ntlworld.com

School of Library, Archive and Information Studies

University College London

Gower Street

London WC1E 6BT

United Kingdom

a.flinn@ucl.ac.uk

\section{REFERENCES}

Agosti, Aldo. 1996. Palmiro Togliatti. Turin, Italy: UTET.

Callaghan, John. 1993. Rajani Palme Dutt: A Study in British Stalinism. London: Lawrence \& Wishart.

Carr, E. H. 1990. What is History? London: Penguin.

CHNN. 2001. Communist History Network Newsletter (Autumn). http://les1.man.ac.uk /chnn/chnn11con.html

Darke, Bob. 1952. The Communist Technique in Britain. London: Penguin.

Haynes, John E. 1996. Red Scare or Red Menace? American Communism and Anticommunism in the Cold War Era. Chicago, Illinois: Ivan R. Dee.

Hobsbawm, Eric. 1998. On History. London: Abacus.

Hyde, Douglas. 1950. I Believed: The Autobiography of a Former British Communist. London: William Heinemann.

KHF. 1995. Klehr, Harvey, John E Haynes, and Fridrikh I. Firsov. The Secret World of American Communism. New Haven, Connecticut: Yale University Press.

KH. 1998. Klehr, Harvey, and John E Haynes. The Soviet World of American Communism. New Haven, Connecticut: Yale University Press.

Mahon, John. 1976. Harry Pollitt. A Biography. London: Lawrence and Wishart.

Morgan, Kevin. 1994. Harry Pollitt. Manchester, England: Manchester University Press. 
2001. "Parts of People and Communist Lives." Pp. 9-28 in John McIlroy, Kevin Morgan, and Alan Campbell, eds., Party People, Communist Lives: Explorations in Biography. London: Lawrence and Wishart.

MCF. 2005a. Morgan, Kevin, Gidon Cohen, and Andrew Flinn, eds. Agents of the Revolution: New Biographical Approaches to the History of the Comintern. Oxford, England: Peter Lang.

2005b. Communists in British Society. London: Rivers Oram.

Pennetier, C., and Pudal, B., eds. 2002. Autobiographies, autocritiques, aveux dans le monde communiste. Paris: Belin.

Portelli, Alessandro. 1998. "What Makes Oral History Different?” In Robert Perks and Alistair Thomson, eds., The Oral History Reader. London: Routledge.

POASM. 2001. "People of a Special Mould." Conference. Website: http://les1.man .ac.uk/cpgb

Rowbotham, Sheila. 1977. Hidden from History: 300 Years of Women's Oppression and the Fight Against It. London: Pluto Press.

Ryan, James. 2000. Earl Browder: The Failure of American Communism. Tuscaloosa, Alabama: University of Alabama Press.

SH. Socialist History. 2002. No. 21: "Red Lives."

Thompson, E. P. 1981. The Making of the English Working Class. Harmondsworth, England: Penguin. 